\title{
Essays
}

\section{The Supreme Court, The Death Penalty, and The Harris Case*}

\author{
Judge Stephen Reinhardt ${ }^{\dagger}$
}

The Harris case was a nightmare. It served no one well. The process was ugly, cruel, injudicious. At a critical time in its history, the American legal system failed to function fairly or well. As a result, that system has been held up to worldwide ridicule. ${ }^{1}$ At a time when we are trumpeting our Constitution as a model for new nations, the leaders of those countries must be wondering how they can find a way to ensure that their courts operate in a wiser and more orderly manner than ours.

The saddest part of all this is that Harris did not just happen. It was no accident. It was inevitable. It was the logical culmination of a series of Supreme Court decisions subordinating individual liberties to the less-than-compelling interests of the state and stripping lower federal courts of the ability to protect individual rights. $^{2}$

* This Essay is a transcript, with annotations, of an address given by Judge Reinhardt at Yale Law School on April 25, 1992.

$\dagger$ Judge, United States Court of Appeals for the Ninth Circuit.

1. See, e.g., Agony on Death Row, THE TMES (London), Apr. 22, 1992, at 1; Phil Reeves \& John Lichfield, Legal Wrangles Prolonged Agony of Harris Execution, THE INDEPENDENT (London), Apr. 22, 1992, at 10; Phil Reeves \& David Usbome, Inside Story: Plop Plop, Fizz, Fizz, THE INDEPENDENT (London), Apr. 26, 1992, at 17; The Five Lives of Robert Harris, ECONOMIST, Apr. 25, 1992, at 22.

2. See, e.g., Coleman v. Thompson, 111 S. Ct. 2546 (1991) (holding counsel's failure to file timely notice of appeal in state court does not excuse procedural default); McCleskey v. Zant, $111 \mathrm{~S}$. Ct. 1454 (1991) (generally limiting prisoners to one habeas corpus petition); Penry v. Lynaugh, 492 U.S. 302 (1989) (holding Eighth Amendment does not bar execution of mentally retarded persons); Teague v. Lane, 489 U.S. 288 (1988) (refusing on collateral review retroactively to apply constitutional ban on race-based 
Yes, Harris was a sad day, or night, indeed. We as a judiciary stand indicted for what we did, exposed for what we are. For that reason I think it essential that there be as much public information as possible concerning what actually occurred and that we learn what lessons we can from our grisly and macabre experience.

Perhaps more importantly, I urge all of you to do what is within your power to preserve the historic role of the federal courts as a guardian of individual liberties. The time has come for the academic world to launch a thorough, high-level study of the Supreme Court's performance in death penalty and habeas corpus cases, its rollback of individual rights and liberties, and its stripping of the powers of lower federal courts to review unconstitutional state actions. I think it clear that the constitutional rights of individuals no longer are of paramount importance to the Court. Other values, other concerns, now predominate.

We in the lower federal courts have little recourse in such circumstances. Whatever our sorrow over the systematic erosion of established rights, we must continue to apply whatever decisions the Court issues. And we will do that. That is our constitutional obligation.

Law schools, deans, faculties, and student bodies have an equally important duty: to subject the judiciary, and particularly the Supreme Court, to rigorous examination; to hold it responsible when it fails in its duties; to do your utmost to safeguard the Constitution against all those who would weaken its values-whether or not they wear black robes; to enlighten the public as to the state of jeopardy into which individual rights have fallen, and, in the process, to help save the historic powers of the federal courts to protect the people of this nation against the arbitrary and abusive exercise of government power.

This week's events in the Robert Alton Harris case demonstrated two principal points, neither new nor surprising, but both of which should concern law schools, lawyers, judges, and the public deeply. The first I have already alluded to: the Supreme Court's concerns over federalism and procedural conformity override its substantive interest in preserving individual liberties. In decisions ranging from Teague v. Lane $e^{3}$ and Penry v. Lynaugh $h^{4}$ to McClesky v. Thompson ${ }^{5}$ and Coleman v. Zant, ${ }^{6}$ the Court has made it plain that the Bill of Rights is no longer its primary concern. What matters to the overwhelming majority of this Court is not whether an individual was convicted in an unconstitutional manner or will be executed in violation of the Constitution, but rather, (a) when did we, the Supreme Court, first make it absolutely clear that the rights which were admittedly violated were protected by the Constitution?

3. 489 U.S. 288 (1988).

4. 492 U.S. 302 (1989).

5. 111 S. Ct. 1454 (1991).

6. 111 S. Ct. 2546 (1991). 
(b) when did the unlawfully incarcerated or to-be-executed defendant file his claim, and did he successfully wend his way through every possible procedural obstacle erected by the state? and (c) did the state consider the question fully and fairly, even if erroneously? But not, I repeat, whether the constitutional rights of the defendant were violated. Harris proves this with a vengeance. With respect to the second point, our ability to handle death penalty cases, let me say first that the act of judging requires a fair, calm, objective, reasoned exploration of facts, law, ideas, and principles based upon adversary presentations-both oral and written-culminating in a reasoned disposition. It is far from clear that we are capable of doing that in at least a substantial number of death penalty proceedings. Many reasons have been given for abolition of the death penalty: we execute the innocent; the process is uncivilized; it is too costly from an economic standpoint; it overwhelms the judicial system; courts are not functionally equipped to handle death penalty cases. Harris goes far toward demonstrating the latter two points.

Let me describe the process as best as I can, starting with last Friday [April 17, 1992]. The governor of California had heard the clemency proceedings during the day on Wednesday and had issued his decision on Thursday evening. On Friday, a $\$ 1983$ case $^{7}$ - a class action-was filed in the district court alleging that the use of the gas chamber constitutes cruel and unusual punishment. ${ }^{8}$ The district court judge, Marilyn Patel, an exceedingly able jurist, quickly ordered a hearing on a temporary restraining order. Calmly, patiently, deliberately, she reviewed the evidence and considered the arguments. She then wrote a careful, well-reasoned, well-balanced opinion that demonstrated beyond any doubt that a temporary restraining order was justified. ${ }^{9}$ Judge Patel behaved in a conscientious and orderly manner that all other judges, federal and state, would do well to emulate.

Temporary restraining orders are ordinarily non-appealable. However, the next day, Saturday, the state sought an extraordinary writ in the Ninth Circuit-a writ of mandamus. We have a procedure in our court by which judges are assigned a death penalty case the first time it comes up, and thereafter that case stays with that panel of judges. ${ }^{10}$ Although this was a class action, the writ seeking to set aside Judge Patel's temporary restraining order was assigned to the panel that had previously adjudicated Harris' death penalty case because the writ was related or ancillary to the earlier proceeding. The panel, consisting of Judges Alarcon, Brunetti, and Noonan, assembled in San Francisco Sunday evening-Easter Sunday-and after internal discussions that I am not free to disclose, a decision was made to have a telephone conference immediately that

7. 42 U.S.C. $§ 1983$ (1988) (creating cause of action for deprivation of constitutional rights under color of law).

8. Fierro v. Gomez, 790 F. Supp. 966 (N.D. Cal. 1992).

9. Id.

10. 9 th Cir. R. 22-2. 
night rather than a full oral argument the following morning. That decision meant that the telephone argument would be held before the respondent's brief could be written-only the state's brief would be before the panel. During the argument the panel advised Harris' lawyers that they would have approximately an hour and a half in which to file their brief. Shortly after the brief was received, at approximately 11:00 p.m., the divided panel publicly announced that the majority had voted to vacate Judge Patel's stay. ${ }^{11}$

A formal order issuing the writ of mandamus was transmitted to the district court on Monday morning. In their decision, which was not distributed until late that afternoon, the majority did not disagree with Harris' contention that use of the gas chamber constituted cruel and unusual punishment. ${ }^{12}$ In fact, Judges Alarcon and Brunetti did not conclude that Judge Patel erred in any of the findings of fact or conclusions of law that she issued in support of the stay; instead they held that the issue was one of abstention - because, they said, the district court was interfering in an ongoing state proceeding..$^{13}$

John Noonan dissented vigorously from this rather remarkable decision. ${ }^{14}$ He pointed out that the state court case was as over as one could be, that the death warrant had been issued, and that nothing remained but the execution itself; he argued that there was no on-going state proceeding and that the majority decision would immunize state capital punishment proceedings from federal habeas review. ${ }^{15}$ Nevertheless, the majority issued the writ on the theory that not only were the federal courts required to abstain, but that the result was so clear that an extraordinary writ was warranted, and that the mandate should be issued immediately-an act which ordinarily deprives the full court of an opportunity to review a panel's actions. Well, that was the last that was and ever will be heard of the abstention theory, because the Supreme Court did not mention it in its subsequent orders, and the panel has since withdrawn its opinion. ${ }^{16}$ The majority ruling was a one-time opinion, good for Robert Alton Harris only. Nevertheless, it accomplished its purpose.

The panel's issuance of the writ of mandamus triggered a remarkable and uncharted process in the Ninth Circuit-and then in the Supreme Court. Unfortunately, although the panel thought the issue was so "clear and indisputable"17 - as the Supreme Court puts the test for mandamus-that a decision could be made immediately, the majority was unable to write a reasoned

11. Gomez v. United States Dist. Court, No. 92-70237, 1992 U.S. App. LEXIS 7931 (9th Cir. Apr. 19, 1992), vacated as moot and withdrawn, 1992 U.S. App. LEXIS 10088 (9th Cir. May 5, 1992), modifying 1992 U.S. App. LEXIS 8857 (9th Cir. Apr. 22, 1992).

12. Gomez, 1992 U.S. App. LEXIS 7931.

13. Id. at **6-7.

14. Id. at $* 9$ (Noonan, J., dissenting).

15. Id. at **14-15.

16. Gomez, 1992 U.S. App. LEXIS 10088.

17. Bankers Life \& Casualty Co. v. Holland, 346 U.S. 379, 384 (1953) (citing United States v. Duell, 172 U.S. 576,582 (1899)). 
explanation until late Monday afternoon. The majority opinion was issued only hours before the scheduled execution. ${ }^{18}$ Until then, no one could be certain about the basis for the panel's action or that the members of the majority would refuse to recall the mandate, thus potentially putting their decision beyond review by the full court and triggering a flurry of activity on the part of their colleagues.

You have probably read that there were four different stays granted on that evening. ${ }^{19}$ That is only partially accurate-one was merely duplicative. Part of the problem was internal communication. We have twenty-eight judges on our court who are spread all over the West, who are dependent on modern science for immediate communication and who utilize equipment that has not been perfected. Trying to resolve difficult life or death issues over electronic mail machines does not under the best of circumstances result in the most orderly or deliberative process, and particularly not when, as on that fateful Monday evening, some of the judges did not receive all the communications, others received some only after the time for voting had passed, and many did not even know what the panel's decision said. There is in fact no substitute for face-to-face discussion among the judges involved when a court must decide difficult or important questions; moreover, there is no substitute for having the relevant parts of the court record physically present at such times. Obviously, neither was possible here. Yet all the judges, fully informed or not, have a duty to vote on life or death issues-whenever the votes are taken. Because the panel's decision was not issued until late in the day on Monday, some stays were issued that might otherwise not have been necessary; some of those stays may have led to public confusion over what was actually transpiring.

In fact, two separate cases were going on at the same time. One was the cruel and unusual punishment case-the gas chamber claim. The other was a habeas corpus claim, which involved an alleged recantation by Harris' brother ${ }^{20}$ The habeas corpus case presented a legal issue similar to one raised in Herrera v. Collins, ${ }^{21}$ a case in which the Supreme Court had granted certiorari. Herrera is a death penalty case in which new evidence allegedly existed indicating that a different person, again a brother, was the actual culprit. Some time before the date of Herrera's scheduled execution the Supreme Court granted certiorari, but refused to grant a stay of execution. The result was that the Supreme Court agreed that it would hear the case, but under its ruling the execution could be conducted prior to the argument. However, two Texas state court judges then issued stays, ${ }^{22}$ so the Supreme Court will now hear the case

\footnotetext{
18. See Gomez, 1992 U.S. App. LEXIS 7931, at *10 (Noonan, J., dissenting).

19. Dan Morain \& Tom Gorman, Harris Dies After Judicial Duel, L.A. TIMES, Apr. 22, 1992, at A1.

20. Harris v. Vasquez, 961 F.2d 1450 (9th Cir. 1992).

21. 112 S. Ct. 1074 (1992) (No. 4).

22. Ex Parte Herrera, 828 S.W.2d 8 (Tex. Crim. App. 1992); Ex Parte Herrera, No. 71,717 (Tex. Crim. App. Feb. 19, 1992).
} 
when the defendant is alive instead of after he is dead. In any event, as of the night of the Harris debacle, the Court had before it in Herrera an issue similar to the one presented in Harris' habeas petition. Thus, grounds existed for a stay in the habeas case, and one was granted-the first stay. ${ }^{23}$ But the habeas case was not Harris' primary challenge. The primary challenge was to the cruel and unusual means of execution.

Ninth Circuit habeas rules provide that when a panel in a death penalty proceeding refuses to grant emergency relief, the normal en banc process, which requires a month for a vote, is modified. ${ }^{24}$ Ordinarily, when any judge asks for an en banc hearing, we have two weeks to debate and two weeks to vote. In a death penalty case, when an emergency vote is called for, we have a total of a seven-day period for both the exchange of memoranda and the actual vote. Seven days is considered the minimum necessary to ensure that all the relevant arguments can be made and answered and that all the members of the court will have an opportunity fully to understand the issues. If the en banc call is made less than seven days before the scheduled execution date, the call for the vote stays the execution until the court decides whether to hear the case en banc.

As I mentioned earlier, the main challenge made by Harris' lawyers was in a civil rights action—the $\$ 1983$ action—and not in a habeas proceeding. The Harris panel decided that while it should exercise jurisdiction over the civil rights case under our habeas rules because the case was related or ancillary to Harris' death penalty proceeding, that exercise of authority was insufficient to justify application of the portion of the habeas rules providing for an expedited en banc proceeding and automatic stay. Instead, the majority said, the normal en banc rules apply and a call for an en banc hearing does not stay the proceedings. ${ }^{25}$ The effect of the majority ruling, if it had been allowed to stand, would apparently have been that the court could have had an en banc hearing in Harris, but only after the execution had taken place-just as the Supreme Court had decided in Herrera that a post-execution hearing would be sufficient.

The panel's actions were not acceptable to a number of judges on the court-either substantively or procedurally. Eleven judges quickly called for an en banc, ${ }^{26}$ in an unprecedented action; normally, only one judge makes such a call. When that call failed to move the panel to order a stay so that the case could be heard before Harris was executed, ten judges signed an order themselves staying the execution. ${ }^{27}$ The purpose was to ensure that the en banc

23. This first stay was unpublished. See Vasquez v. Harris, 112 S. Ct. 1713 (1992) (No. 4) (vacating first stay).

24. 9TH CIR. R. 22-2.

25. Gomez, 1992 U.S. App. LEXIS 7931.

26. The call for a vote on whether to review en banc the three-judge panel was done by electronic mail.

27. Gomez v. United States Dist. Court, No. $92-70237$ (9th Cir. Apr. 20, 1992) (Hug, Fletcher, Pregerson, Poole, D.W. Nelson, Norris, Canby, Reinhardt, Noonan, \& T.G. Nelson, J.J.) (second stay). 
deliberations could occur before they were rendered futile. This ten-judge stay order was the second stay.

While the ten judges were issuing their stay, an effort was underway to obtain the votes of a majority of the court to override the panel's interpretation of the habeas rules. To some of the judges on the court, the panel's interpretation of the rules did not make much more sense than its mandamus decision. To others, there was a logical gap in the rules that needed immediate filling. To supporters of the panel's interpretation, it appeared that the majority had simply applied the rules as they were written, and that any changes would have to be made in accordance with our regular amendment procedures. The override process took a substantial amount of time. In fact, it wasn't completed until approximately half an hour before the execution was scheduled, and even then a number of the judges were not clear about what issue the vote concerned, whether they were supposed to vote, just what was going on. At least some judges had not received a number of critical communications regarding the rapidly developing events, and some were not even given the opportunity to vote. None of this was intentional or motivated by malice. There simply was not sufficient time for the regular process to work in an orderly manner. In fact, by the time enough votes were obtained to override the panel's interpretation of the rules-to construe those rules as requiring that a stay be issued-the stay simply duplicated the one that had already been issued by the ten judges of the court. ${ }^{28}$ Thus, the so-called third stay was of absolutely no practical significance-except that it confused the press and the public, and possibly some of the other players in the proceedings.

While all of this was transpiring out West, the members of the Supreme Court, secure in their homes, were following the activities of our court with great interest. The Justices vacated the stay in the habeas case fairly quickly. ${ }^{29}$ But the problem that consumed both courts was the series of stay orders in the cruel and unusual punishment case. Everyone knew that what happened with respect to the stays regarding the use of lethal gas would determine whether the state officials would rush eagerly into an execution that morning or the courts would have an opportunity to consider the constitutional claim in an orderly manner.

At six o'clock Tuesday morning Eastern time, the Supreme Court Justices decided by a seven to two vote that the federal courts should not consider the cruel and unusual punishment claim on the merits because it had not been raised in a previous habeas petition. ${ }^{30}$ In its opinion, the Court did not say that the manner in which Harris was about to be executed was constitutional; none of the seven Justices even suggested that. Instead, the majority of the Justices

28. Gomez v. Vasquez, No. 92-55426 (9th Cir. Apr. 20, 1992) (third stay).

29. Vasquez v. Harris, 112 S. Ct. 1713 (1992) (No. 4) (vacating first stay).

30. Gomez v. United States Dist. Court, 112 S. Ct. 1653 (1992) (per curiam) (vacating second stay). 
vacated the stay issued by ten appellate court judges on the ground that the claim was brought too late. ${ }^{31}$ They also stated that were they to consider the claim on the merits, they would deny it as a matter of equity. ${ }^{32}$ The Court declared that on one side the equity was that California was inconvenienced because the claim was brought at a late stage in the proceedings. It didn't mention what the equity was on the other side, although the nature of that equity was obvious: a man would be executed by potentially unconstitutional means. Without ever acknowledging the equity on Harris' side, the Supreme Court found that the equities in favor of the state-namely, that the claim was filed at a later time than the Justices considered appropriate- outweighed any interest Harris might have in the right afforded him by the Constitution-not to be executed in a cruel and unusual manner. ${ }^{33}$ The only two Justices who reached the merits of the claim, Justice Stevens and Justice Blackmun-two moderate Justices, both appointed by Republican Presidents-thought that Harris' constitutional argument was correct and that his execution by lethal gas would in fact violate the Eighth Amendment. ${ }^{34}$

Now, at six in the morning, when the Justices, by whatever process of deliberation, reached their conclusion, the word that came back to the judges on the Ninth Circuit was simply that the stay had been vacated; the execution would go ahead. No explanation of the Supreme Court's reasoning was immediately available. It was 3 a.m. Pacific time. Most Ninth Circuit judges were asleep. Harris' lawyers called one of them and woke him up. He was Judge Harry Pregerson, a man whom I am extremely proud to have as a colleague. $\mathrm{He}$ is a dedicated, fearless ex-marine, who told the United States Senate when he was confirmed that he would always follow his conscience, that he would always act in a manner that he thought the Constitution required, no matter what. That is what Judge Pregerson has always done; that is what he did in this case.

When Judge Pregerson was told that the Supreme Court had vacated the stay, he knew that the majority of the Harris panel had said that Harris was in the wrong court-and that the Supreme Court had lifted the order of the ten judges staying that decision. As far as Judge Pregerson knew-and in fact as far as was the case-not one judge had ever said that Harris' cruel and unusual punishment claim lacked merit. Judge Patel had found that there was a sufficient showing on the merits to justify issuance of a stay and had given very detailed reasons as to why Harris had a substantial constitutional claim. Judge Noonan had agreed, as did Judge Pregerson. (As noted, Justices Stevens and Blackmun subsequently went much further, they concluded that Harris' claim was correct.) On the other side of the equation, the majority of the Harris panel

31. Id. at 1653 .

32. Id.

33. Id.

34. Id. at 1653-56 (Stevens, J., dissenting). 
had decided only that abstention applied, that Harris should be in a different court. And the Supreme Court had vacated the stay of that panel's order. In short, it appeared to Judge Pregerson that the Harris panel's abstention order had been reinstated. Judge Pregerson also knew that under the law any single judge is authorized to issue a stay when an emergency exists. ${ }^{35}$ Therefore, when he got a call from Harris' lawyer, who said, "Our man is about to be executed. Your court said he should be in state court. Will you give us a stay so we can go there?" Judge Pregerson did what any honorable judge with a commitment to the Constitution would have done; he granted a twenty-four hour stay and said, yes, you may now go to state court. That was the fourth and final stay. ${ }^{36}$

Well, of course, the Supreme Court couldn't be aware of everything that was occurring on the scene, 3,000 miles away, and apparently, the Justices did not stop to consider what Judge Pregerson knew or didn't know when he issued his order. Some of them may even have thought that Judge Pregerson was disregarding their message that Harris' claim came too late and that, as far as they were concerned, it was immaterial whether he was being executed unconstitutionally or not. Judge Pregerson had not, however, had the opportunity to review any order issued by the Supreme Court, and quite understandably did not assume that the Court would say, "we don't care whether or not we execute people unconstitutionally." It was far more reasonable for him to assume, for example, that the Justices had agreed with the panel's ruling that Harris was in the wrong court. In any event, there was not much time for Judge Pregerson to engage in a painstaking analysis of the Supreme Court's rationalizations. Harris was about to die. Moreover, even if Judge Pregerson had known that the Supreme Court did not wish the federal courts to entertain the cruel and unusual punishment claim on the ground of timeliness, that did not necessarily mean the state courts would be unwilling to do so. Accordingly, Judge Pregerson gave Harris' attorneys time to go to "the right court." The Supreme Court Justices, who by that time must have started on their morning coffee, reacted swiftly. They immediately entered another order, one without precedent in our jurisprudence. The Supreme Court not only vacated Judge Pregerson's order but stripped all lower federal courts of their authority to act in the Harris case $^{37}$ - an order that can be explained only in part by the Justices' lack of sleep. The execution then occurred without any further involvement on the part of the federal courts, as would have been the case with or without the Supreme Court's final order.

Some of the first news reports suggested, based on the comments of one or more law professors who had no familiarity with any of the orders involved,

35. 9TH CIR. R. 22-04(e)(4).

36. Harris v. Vasquez, No. 92-70237 (9th Cir. Apr. 21, 1992) (fourth stay).

37. Vasquez v. Harris, 112 S. Ct. 1713 (1992) (No. 5) (vacating fourth stay). 
that the night's events involved a measure of defiance of the Supreme Court. The Los Angeles Times reported that a professor from Berkeley and one from Stanford had said that the acts of some Ninth Circuit judges approached civil disobedience. ${ }^{38}$ That characterization was, of course, totally false, and demonstrates a complete ignorance of the chronology. In reality, the Ninth Circuit has followed and will follow all Supreme Court decisions no matter how offensive they may be to the sensibilities of those judges who believe that the courts are supposed to protect the individual against the state and not the state against the individual.

The Harris fiasco was not a result of liberal judges opposed to the death penalty seeking to halt an execution. Justices Stevens and Blackmun hardly fit in that category. Nor was that the motivation of the ten judges of the Ninth Circuit who signed the stay order. Those judges sought instead to have constitutional claims resolved by orderly procedures in accordance with due process of law. In my opinion, had they done less, they would have failed in their constitutional obligation.

At the outset, I described what an act of judging is-listening to arguments, hearing both sides, weighing the law, and making a careful, reasoned decision. Without assessing fault, I can say with sadness that I do not believe that our court lived up to that standard on the trying evenings in question. As to the Supreme Court, the ultimate judgment may be even harsher. Anyone considering the history of Robert Alton Harris' last moments and especially the final, unprecedented Supreme Court order must ask himself (or herself) a number of questions: First, is it proper for the Supreme Court to issue an order denying all other federal courts the ability to exercise the power given them, not by the Supreme Court, but by law? Was this extraordinary action a proper and lawful exercise of legitimate power? Next, is it the proper role of the Supreme Court to supervise and administer individual executions? Is that why the Justices are there? I was taught in my time at Yale Law School that the Supreme Court's role is not to attempt to correct individual errors but to decide cases involving general principles; to establish the overriding law. That is why the Court takes only a small number of cases a year, yet is able to have such a significant effect on the administration of both the civil and criminal law. Is it the proper role of the Court to sit up all night, the individual Justices in their bedrooms, issuing a series of orders designed to control the outcome of a single case, to see that someone is executed on one day rather than another? Is that a proper exercise of the Supreme Court's authority? Is that seemly behavior for the highest Justices of our land? It is not my function to answer those questions; it is the responsibility of those of you in the academic world. I hope you will consider them carefully, and let us in the judiciary know what you decide.

38. Richard C. Paddock \& Philip Hager, Legal Chaos Over Harris Reveals a Clash of Views, L.A. TIMES, Apr. 23, 1992, at A1. 
What was most offensive to a vast number of people was the gruesome strapping and unstrapping of Robert Alton Harris in the gas chamber, the filling of the vats beneath his chair with the deadly acid, the subsequent temporary displacement of that acid, and ultimately Harris' silent removal from and eerie return to the death chamber.

Why? What makes civilized people behave in this manner? Why the unwillingness to permit an orderly, calm, reasoned, judicial resolution of what was admittedly a serious constitutional claim? Whose unwillingness? Certainly not the Ninth Circuit's.

While it is not my role to assess blame, surely it is appropriate to identify responsibility. The responsibility for the on-again, off-again procedure lies squarely with the Supreme Court, not the lower courts, which generally tried their best to do their job in a fair and orderly manner. The series of rapid-fire early morning Supreme Court reversals was extraordinary, to say the least. And most certainly those reversals must be held to be the cause of the night's ultimate series of occurrences.

The problem in the Harris case may well be inherent in any death penalty litigation. Death cases are unique. The Supreme Court has repeatedly told us so. They are different in terms of finality. There is no room for error. As far as I am concerned, personally, we cannot tolerate executions of innocent people or executions that violate the Constitution. Some, including a majority of the Supreme Court, may disagree. Those Justices have the responsibility and the right to determine what the law is, and, as I have said, once that law is established, we will follow it. However, it is your responsibility to examine what the Court is doing. It is your responsibility ultimately to measure its performance, and to help the people to decide whether our rules should permit the execution of innocent people and the execution of people in violation of the provisions of the Constitution.

Are such executions really consistent with our laws? The Supreme Court may give its answer to that question soon, in Herrera, ${ }^{39}$ if it has not already done so in Coleman ${ }^{40}$ and Penry. ${ }^{41}$ In Herrera the argument is being made to the Court that it is cruel and unusual punishment to execute a person who is innocent of a capital offense. Now, it would seem to a layman to be fairly obvious that the execution of innocent persons is contrary to the fundamental guarantees prescribed by our Constitution. But those of you who are versed in the law know that it is not that simple-at least to some. The argument on the other side is that if a trial is held in compliance with constitutional procedures-if during that trial there is no violation of constitutional rules-then, there can be nothing fundamentally wrong with the trial, with the convic-

39. Herrera v. Collins, 112 S. Ct 1074 (1992).

40. Coleman v. Thompson, 111 S. Ct. 2546 (1991).

41. Penry v. Lynaugh, 492 U.S. 302 (1989). 
tion-because there is nothing unconstitutional about what occurred. In such cases, the error lies only in the result, and guilt or innocence is not a constitutional question. So, at least, say those who argue in the name of federalism that federal courts of appeal and federal district courts may not intervene simply to free the innocent. We must leave such matters to the state courts, they tell us-and if the state courts fail in a particular case, that is a part of the price we pay for our form (or structure) of government.

Fortunately, the answers are not yet all in, although the not so early returns from Washington are foreboding. Some of the issues may still be open, at least partially. Some of them will soon be coming to the federal appellate courts and then very rapidly from us to the Supreme Court. This is a time when we need firm answers and we need them from those who can do a better job than some now wearing robes (including Yale graduates) seem able to do. This is one of the reasons it is so important for the academic world, for today's Yale Law School, to speak up, to educate the public, to try to influence the Court, and to revitalize the Constitution.

One of the premises I began with is that the courts may be functionally incapable of handling death penalty cases fairly and judiciously. That was certainly true in Harris. Judge Patel tried to establish an orderly process and it broke down. She issued a temporary restraining order only after receiving evidence from both sides and conducting a full oral argument. The plaintiff's evidence, which is summarized in Justice Stevens' dissent was very strong, ${ }^{42}$ measured by the standards applicable to temporary restraining orders. Judge Patel then set a hearing on a preliminary injunction, as required by law. That hearing never took place, because of the orders issued by the Harris panel and the United States Supreme Court. The turmoil in our court, partly engendered by the complex mechanics required to fully inform a geographically dispersed court of twenty-eight active judges, speaks ill of our ability to handle such emergencies. On the other hand, in all fairness, it was only our first full-scale attempt under emergency conditions. (A week or two before, in Harding $v$. Lewis, $^{43}$ an Arizona death penalty case, a different three-judge panel of our court received the appeal on Thursday. It issued an order on Thursday postponing the scheduled execution for twenty days so that it could review the briefs and record ${ }^{44}$-only to have the Supreme Court vacate the order on Saturday. ${ }^{45}$ The three- judge panel never had a chance to consider Harding's appeal on the merits. He was executed on schedule Sunday night).

There are approximately three hundred prisoners on death row in California alone. Whether or not we can handle last-minute appeals is one question; whether, regardless of timing, we can handle the volume of death penalty

42. Gomez, 112 S. Ct. at 1653-56 (Stevens, J., dissenting).

43. No. Civ. 92-209 TUC AM, 1992 U.S. Dist. LEXIS 8671 (D. Ariz. Apr. 3, 1992).

44. See Lewis v. Harding, 112 S. Ct. 1580 (1992) (vacating Ninth Circuit's stay of execution).

45. Id. 
cases-all difficult cases, all complex cases-is another. What the effect will be on the judicial process is a third. We are presently barely able to handle our current caseload properly. We are constantly curtailing the rights of litigants to present argument, oral and written, because we don't have enough time to consider their cases fully. We are always looking for new fast-track procedures-which means less careful, less thorough review of cases on the merits. And that's without the flood of death penalty cases. We have recently cut the time for oral argument in complex cases from thirty minutes to twenty minutes per side and in the "simpler" cases from fifteen to ten. We have just adopted a rule reducing the maximum size of briefs. The reason for these changes is that we simply don't have the time to devote to cases that courts had in the past. And now our circuit is considering proposals that would result in a significant reduction in the percentage of cases to be argued, a step that in my view would be disastrous from the standpoint of judges and litigants alike.

When I came on the court ten years ago, we wrote reasoned opinions in about seventy-five percent of our cases. We now write them in about twentyfive percent. In the large majority of our cases, we write memorandum dispositions which are unpublished. It is no secret that there is not as much time, attention, or care given to the disposition of cases decided in memoranda. The theory is that many of the cases do not require the same degree of effort as those we treat in published opinions. In some instances this is true. In others, the theory is right, but the reality is not. In my opinion we gloss over a number of difficult issues when we handle cases informally. And if we now adopt procedures which make it impractical to hear significant numbers of the types of cases we have previously heard, the quality of justice in our courts will be reduced even further.

There is simply no doubt that if we had more time, we would do a better job on all of our cases. If we are now going to add three hundred death penalty cases in California alone to our caseload-and I see no alternative in sight-not only will we not be able to handle those death penalty cases properly, but we will not, in all likelihood, be able to handle any of our cases in a manner that is consistent with the standards that have traditionally marked the federal courts.

There's nothing different in this respect about the Ninth Circuit except that we happen to have the largest number of defendants awaiting execution. Otherwise, the problems we face are those faced by the judiciary in general. They are problems that the public must consider when it decides whether it wants to pay the price that the retention of the death penalty requires. Judges have to handle the cases we're given, but the public must understand the effect that the mounting capital caseload will have upon the courts and upon our ability to do justice in the multitude of non-capital cases awaiting our attention.

Now, for the most difficult problem in death penalty cases-appeals that come at the last moment, constitutional claims of innocence or otherwise that 
are raised shortly before the scheduled execution date. Such was, of course, the nature of Harris' lethal gas claim.

Harris had had a number of prior habeas cases. They were not frivolous. In the most recent habeas case that had come before our court Harris had sought a hearing regarding the inadequacy of the forensic psychiatric counsel he received at his trial. ${ }^{46}$ His mother was an alcoholic. His father had beaten her while she was pregnant, and had beaten Harris from the time of his birth through adolescence. Scientific knowledge concerning the effects of child abuse, and particularly of "fetal alcohol syndrome," was at an elementary stage at the time of Harris' trial. It is arguable whether the alleged failure to present that issue properly raised an issue regarding a negligent failure to present relevant evidence, regarding newly discovered evidence, regarding newly developed scientific evidence, or a combination of all. Whatever the case, there was a serious constitutional question as to the adequacy of Harris' psychiatric defense, a question which, under Ake v. Oklahoma ${ }^{47}$ might have precluded the imposition of capital punishment. The habeas proceeding involving that issue was decided in our court by a 2-1 vote. The panel was the same as the one that ultimately decided Harris' final claims. The majority, consisting of Judges Alarcon and Brunetti, refused to order an evidentiary hearing on Harris' contention regarding constitutionally inadequate psychiatric assistance. ${ }^{48}$ Judge Noonan dissented. ${ }^{49}$ There was an en banc call in the earlier case also, and, according to a report in the Los Angeles Times, the call failed by a 13-13 vote. ${ }^{50} \mathrm{I}$ mention these facts to make it clear that we are dealing not with a man who has been guilty of filing a series of frivolous appeals solely for the purpose of delay, but with a man who has raised a series of substantial constitutional questions that the courts have treated seriously.

Having finally lost on the question whether the state could legally execute him, Harris' penultimate step was to obtain a clemency hearing before the Governor of California. A week before that hearing, an event occurred that dramatically affected the course of Harris' last days. For the first time in 25 years an execution by means of lethal gas took place in the West. There had been few if any executions in our circuit during that entire period. I recall only one-a case in which the defendant refused to appeal. ${ }^{51}$ Actually, there had been very few executions anywhere in the United States during the time in question; almost all had been in the South, and almost none had involved the use of lethal gas. In fact, the last time the gas chamber had been employed in

46. Harris v. Vasquez, 943 F.2d at 934.

47. 470 U.S. 68 (1985).

48. 943 F.2d at 945 .

49. Id. at 962 .

50. See Dan Morain, Harris Case Splits Appeals Court, L.A. TMEs, Dec. 4, 1991, at A3.

51. Lanhard v. Wolff, 603 F.2d 91 (9th Cir. 1979); see Bill Curry, Bishop Granted His Wish: Death Without Delay, WASH. POST, Oct. 22, 1977, at A3. 
the United States had been in Mississippi in the early 1980's. Immediately prior to that execution the Fifth Circuit had ruled that the use of the gas chamber did not violate the Constitution. ${ }^{52}$ However, shortly after the execution, Mississippi changed its laws and proscribed the future use of that form of capital punishment. . $^{53}$

The execution a week or so before Harris' took place in Arizona's gas chamber. ${ }^{54}$ Witnesses to the execution, including press witnesses, described it as a horrible occurrence..$^{55}$ As a result the Attorney General of Arizona announced that he would recommend that Arizona change its laws to eliminate the use of lethal gas. The events received widespread coverage in the California press.

Governor Pete Wilson denied Harris' clemency appeal on the Thursday evening before the scheduled Monday night execution. ${ }^{56}$ There had been some doubt as to what the Governor would do because earlier, as a United States Senator, he had spoken out forcefully on the subject of fetal alcohol syndrome. In the end, Governor Wilson announced that while he sympathized with "the boy," he had no sympathy for "the man." The next day, Harris' lawyers filed their civil rights case. They relied heavily on the recent Arizona experience. I will offer no comment on the merits of Harris' claim. However, by the standards applicable to temporary restraining orders, it was certainly not insubstantial-just as Harris' claim with respect to Ake v. Oklahoma ${ }^{57}$ and fetal alcohol syndrome was clearly not insubstantial.

Could Harris' lawyers have challenged the method of execution earlier? Yes. Should Harris have been executed because they didn't? The Supreme Court, as I said, weighed the equities and found that they favored the state because Harris' lawyers waited too long. The Court said it was making an equitable judgment; it wasn't applying the law; it wasn't looking at cases; it was applying equity. This of course raises equitable questions in turn for those who must evaluate the Court. What is fair? What is just? What are our moral values? Are the Supreme Court's values consistent with the fundamental principles embodied in our Constitution?

The Supreme Court's moral values led it to conclude that delay by a lawyer outweighed any interest the defendant had in not being executed by cruel and unusual means. That is a moral value the Court is free to adopt. The question is, however, does that truly represent the moral values of this civilized nation? Perhaps it does. If so I would say it speaks ill of the moral state of our society.

52. Gray v. Lucas, 710 F.2d 1048 (5th Cir. 1983).

53. Miss. CODE ANN. § 99-19-51 (Supp. 1991).

54. See Gruesome Death in Gas Chamber Pushes Arizona Toward Injections, N.Y. TMMS, Apr. 25, 1992 , at 9.

55. Id.

56. Dan Morain \& Daniel M. Weintraub, Wilson Rejects Plea of Mercy for Harris, L.A. TMES, Apr. 17, 1992, at Al.

57. 470 U.S. 68 (1985). 
Just one more word about Harris' lawyers. You might ask yourselves as present and future members of the profession, did Harris' lawyers actually delay unreasonably in not bringing the gas chamber claim earlier? Should they have diverted any part of their effort to save his life to litigating the means of his death prior to the time it was finally determined that he would be executed? What kind of message would it have sent to the courts and particularly to the Governor to initiate an early public debate over the method by which their client should be executed? Finally, did not Harris' lawyers strengthen their case on the merits substantially by waiting until the question of how he should die was "ripe"? Lawyers who bring cases too early may use up their only chance at the system and may find to their chagrin that they brought the action before all of the necessary evidence was available. Here, as it turned out, the Arizona gas chamber experience provided the only recent evidence of the practical effects of using lethal gas. That evidence could not have been presented at all had the action been filed during the only time the Supreme Court thought was appropriate.

But what about last minute claims in general? Claims of innocence, newly discovered evidence, newly developed law, newly developed scientific procedures that could affect the result? Claims of recent discovery that the prosecution concealed material evidence or knowingly used perjured testimony? Some of these are subjects the Supreme Court has already considered. Some are subjects the Justices may consider soon. Let us begin our analysis by acknowledging that some last minute claims are "sham." If there is no substance, no basis, to a defendant's last minute appeal, the federal courts are perfectly capable of dealing with the matter expeditiously. The district court can summarily reject a wholly meritless claim, and the circuit court can swiftly dispose of any frivolous appeal. There is no problem with any of that. However, no one contends that Harris' case was a sham, that he didn't present a constitutional question of the first order. So what do we do about legitimate claims of innocence, or substantial claims of violations of constitutional rights when they are raised late? Finality is a valid concern, but should it be the only one? My purpose here is not to attempt to analyze what the Supreme Court has recently held with respect to last minute claims or even with respect to claims brought at a reasonably early date when they are contained in a second or "successive" habeas petition. Nor am I here to comment on the consequences of the Supreme Court's drastic if not revolutionary revision of the law in this area-or on its use of judicial fiats to accomplish its goals. I will not even comment on the Court's startling end-runs around the legislative branch of government in these areas. Rather, I am asking you as teachers and students of the law to consider a question that is critical to all of us, and to help us by giving us your response. I am asking you-what is the proper answer of a civilized society to the problem of last minute proceedings in which a capital defendant alleges newly discovered evidence that will establish his innocence or will demonstrate that 
his constitutional rights have been violated-claims that are substantial and not sham.

To get you started: I see three alternatives. One, we can execute people unconstitutionally, guilty or innocent, and simply say, "Too bad, your lawyers should have spoken up earlier; they should have done a better job in their representation of your interests; because they didn't, you pay the ultimate penalty." Two, we can say that we cannot cope; so let's do away with the death penalty. Three, we can handle these claims in an orderly manner in accordance with due process of law. Certainly the Harris decision, along with others, demonstrates the Supreme Court's strong leaning toward the first option. Option two, the elimination of capital punishment, is a broader question, one that is beyond the scope of this presentation. While our difficulty in handling capital punishment cases may help provide relevant information to the ultimate decisionmakers, the answer as a whole lies with our legislators and the voters, at least for the foreseeable future. From a practical standpoint, we must assume that capital punishment will be with us for the indefinite future. Thus, option two is not a practical one.

I will assume that some of you at least will arrive at the third answer, that legitimate last-minute claims-claims that raise a substantial question of innocence or constitutional violations-must be handled fairly, justly, and expeditiously. At the same time we must recognize the existence of justifiable concerns regarding undue delays, and the procedural morass in which capital punishment cases too often appear to become entangled. Those who favor option one, a swift end, finality, a rigid bar, are frustrated by the inability to obtain what one of the relatives of a youth murdered by Harris called "closure." H8 Her frustration was understandable. If we are to have capital punishment, there must be a way of bringing the proceedings to an end within a reasonable time. The families of victims, and society as a whole, are entitled to that. So let us agree that even for those of us who favor the third option there must be finality. The question is, how do we achieve it and at what price?

Should we draw firm lines with respect to the number of claims we permit? One habeas claim, for example? Or with respect to the time within which a claim must be presented-x months before the scheduled date of execution? The problem with absolutist solutions is that, if really pressed, the reasonable advocates of such a system must acknowledge that no approach can be applied inflexibly-unless we are willing to sacrifice fairness and justice. There must be exceptions made in individual cases, exceptions that would put the courts back into the business of handling last minute claims, and the lines we would be required to draw, or the categories we would be required to establish, are exceedingly difficult to define. Still, the only alternative to a reasonable degree

58. Alan Abrahamson, Sister of Harris Victim "Felt Peace" at the End, L.A. TMES, Apr. 22, 1992, at $\mathrm{Al}$. 
of flexibility is the approach I have described as option one: no matter what, guilty or innocent, constitutional or unconstitutional, review is foreclosed, the execution must proceed. I would hope that no reasonable person, faced with irrefutable proof of innocence, would say, "Too late, gas him." Similarly, I would hope that no reasonable person would advocate proceeding with an execution if it were clear that the person was being executed on the basis of false or perjured testimony and that but for that testimony he would not have been condemned to death. There are lots of other examples, of course. So back to option three: resolve last-minute claims in an orderly, judicious, and expeditious manner.

Some of the frenzy over the perceived need to have executions go forward on the scheduled day results from laws voluntarily enacted by some of the states. California law provides that if a condemned person is not executed on the day the state court sets, that court must hold a new hearing and fix a new execution date which may be anywhere from thirty to sixty days after the date of the new hearing. ${ }^{59}$ Judges understandably fear that if the original execution day passes, a whole new cycle of claims and appeals will be launched. That fear might well be eliminated, or at least drastically reduced, if states were to change the laws that require that the execution take place on a specific date, by adopting reasonable exceptions to the rule, including exceptions for delays caused by certain court stays. The passage of a particular date would then no longer have the emotional or psychological impact that apparently caused the members of the United States Supreme Court to spend such a long and difficult night making certain that Robert Alton Harris' execution took place within a specific twenty-four hour period.

What should be the test regarding last-minute appeals in a moral society devoted to constitutional principles? I would start from the premise that we must adjudicate fairly, judiciously and expeditiously, all such claims which raise substantial and legitimate questions. The only question in my mind is whether we need to improve our procedures in order to ensure that we do so in a manner that society will find more acceptable. Last-minute claims need not consume an inordinate amount of time or entail undue delay. While death penalty cases in general are terribly complex and ordinarily present a vast number of issues, last-minute death penalty appeals are different. Almost all potential issues have been exhausted by the time a last-minute death penalty appeal is filed. The final appeal usually involves a single, finite question. There should be no great difficulty in handling all such appeals fairly, judiciously and promptly.

Short cuts that deprive the condemned person of a fair hearing are not the solution to legitimate claims. Orderly and fair procedures are. We can certainly take another look at our rules and learn from our experience-as I am certain 
our court will. We can also benefit from the views of the academic community. In the end, we must find a way to persuade the public that we cannot execute people who may be innocent, or who present substantial claims of constitutional violations, simply because we are dissatisfied with the length of time it takes to handle their claims. Death is too fearful a penalty for delay, for incompetence or for neglect of counsel or even, as the court viewed it in Harris, (erroneously I believe) for counsel's effort to manipulate the system.

It's been a long afternoon-and it was an awfully long couple of nights earlier this week. In closing, I want to return to perhaps the most important issue to arise out of the disastrous Harris proceeding: what are the limits of the Supreme Court's authority over lower federal courts? May the Court prohibit Article III judges from exercising their statutory authority, and if so, under what circumstances? The issue is not limited to death penalty questions; it is one that may have far reaching implications in various areas of the law. It should cause us to consider most seriously Justice Thurgood Marshall's parting words ${ }^{60}$ - and to try to determine what those who love the law and the Constitution can do to help remedy the overarching problem he described.

Having said all that, I hope that someday in the not too distant future we in the world of the judiciary will hear from you. We badly need your help.

60. "Power, not reason, is the new currency of this Court's decisionmaking." Payne v. Tennessee, 111 S. Ct. 2597, 2619 (1991) (Marshall, J., dissenting). 
. 